\title{
Diosgenin-induced autophagy and apoptosis in a human prostate cancer cell line
}

\author{
CHAO NIE $^{1}$, JIE ZHOU $^{1}$, XIAOKANG QIN $^{2}$, XIANMING SHI $^{1}$, \\ QINGQI ZENG ${ }^{1,3}$, JIA LIU ${ }^{1}$, SHIHAI YAN ${ }^{3}$ and LEI ZHANG $^{1}$ \\ ${ }^{1}$ Department of Research Office, Jiangsu Jiankang Vocational College, Nanjing, Jiangsu 211800; \\ ${ }^{2}$ Nanjing KeyGen Biotech Co., Ltd., Nanjing, Jiangsu 211100; ${ }^{3}$ Department of Oncology, \\ Affiliated Hospital of Nanjing University of Chinese Medicine, Nanjing, Jiangsu 210029, P.R. China
}

Received September 18, 2015; Accepted August 2, 2016

DOI: $10.3892 / \mathrm{mmr} .2016 .5750$

\begin{abstract}
Diosgenin, a plant steroid compound from Dioscorea nipponica, is an anti-inflammatory, antidiabetic, antitumor, vasodilatory compound, which also reduces blood lipid content and protects against ischemia-induced neuronal damage. However, a limited number of studies have been performed on the antitumor effect of diosgenin on prostate cancer, the underlying mechanism of which remains to be fully elucidated. In the present study, the effect and underlying mechanism of diosgenin on DU145 human prostate cancer cells was investigated. DU145 cells were cultured in vitro with diosgenin, following which cell proliferation was detected by a 3-(4,5-dimethylthiazol-2-yl)-2,5-diphenyltetrazolium bromide assay and apoptosis was detected by flow cytometry. In addition, DU145 cells were observed under a transmission electron microscope to confirm autophagy. monodansylcadaverine staining and western blotting indicated the levels of autophagy in DU145 cells. To determine the mechanism underlying the effect of diosgenin on DU145 cells, western blotting was performed to evaluate the involvement of the phosphatidylinositol 3 kinase (PI3K)/protein kinase $\mathrm{B}(\mathrm{Akt}) / \mathrm{mammalian}$ target of rapamycin (mTOR) signaling pathway. To investigate the association between apoptosis and autophagy, DU145 cells were cultured with diosgenin and 3-methyladenine. Hoechst 33342/propidium iodide double staining was performed to detect apoptosis, and reverse transcription-quantitative polymerase chain reaction was used to analyze mRNA expression levels of Beclin 1 and B-cell lymphoma 2. Diosgenin inhibits the proliferation of DU145 cells by activating apoptosis and autophagy, and the mechanism underlying this activation may be associated with the inhibition of the PI3K/Akt/mTOR signaling
\end{abstract}

Correspondence to: Professor Lei Zhang, Department of Research Office, Jiangsu Jiankang Vocational College, 129 Hanzhong Road, Qinhuai, Nanjing, Jiangsu 211800, P.R. China

E-mail: jsjkzl@outlook.com

Key words: diosgenin, DU145 cells, autophagy, apoptosis pathway. In addition, the inhibition of autophagy mediated by diosgenin increases apoptosis and, thus, increases the therapeutic effect. The combination of diosgenin with an autophagy inhibitor may be an effective strategy to increase the antitumor effect of diosgenin.

\section{Introduction}

Prostate cancer primarily occurs in older males over 75 years of age (1). The American Cancer Society predicted that 238,590 people would be diagnosed with prostate cancer in 2013 , and that 29,720 patients would succumb to the disease. An aging population and the effects of the environment, stress and diet have resulted in substantial year-on-year increases in the number of prostate cancer patients. Prostate cancer is now the second most common cause of cancer-associated mortality in males in the USA (2) and severely affects quality of life and life expectancy (3). Therefore, the identification of novel strategies to diagnose and treat prostate cancer is crucial. Currently, prostate cancer therapies primarily involve surgical resection, radiotherapy, chemotherapy and endocrine therapy. However, the application of these therapies is limited by the relatively high age of onset meaning patients may be frail, the local metastasis of the disease and the tendency for postoperative relapse (4-10). Previous studies have reported that traditional Chinese medicine possesses antitumor (11-13) and anti-inflammatory (14-16) effects, increases immunity (17), restores the normal functions of the bone marrow, blood and gastrointestinal tract, and improves quality of life $(18,19)$. Therefore, traditional Chinese medicine may potentially be useful for the treatment of cancer.

Diosgenin is a plant steroid compound that is isolated from the root of Dioscorea nipponica of the Dioscoreaceae family and is an active ingredient in a variety of traditional and patented Chinese medicines. In addition, diosgenin (molecular formula, $\mathrm{C}_{27} \mathrm{H}_{42} \mathrm{O}_{3}$; molecular weight, $414.61 \mathrm{Da}$ ) is an important raw material in the synthesis of steroid agents. Previous studies have demonstrated that diosgenin possesses antitumor $(20,21)$ and antidiabetic $(22,23)$ activities, reduces blood lipid content (24), acts as an anti-inflammatory (25) and vasodilator (26), and protects the myocardium (27). With 
regards to the antitumor effects of diosgenin, it has been demonstrated to inhibit the growth of multiple tumor types, including breast, esophageal, liver and gastric cancers (28-31), however, few studies have investigated its effects on prostate cancer. Furthermore, the mechanism underlying the antitumor effect of diosgenin remains to be elucidated. It is widely accepted that apoptosis is an important cell death pathway. In addition, autophagy has been demonstrated to be involved in tumorigenesis. Therefore, the present study used the DU145 human prostate cancer cell line to investigate the effect of diosgenin on the proliferation, apoptosis and autophagy of prostate cancer cells. In addition, the mechanism underlying the action of diosgenin was examined, to provide experimental evidence supporting the use of diosgenin as a potential treatment for prostate cancer.

\section{Materials and methods}

Chemicals and reagents. Diosgenin was purchased from Nanjing Zelang Medical Technology Co., Ltd. (Nanjing, China), with a purity of $>98 \%$ as determined by high-performance liquid chromatography. Minimum essential medium (MEM), 3-(4,5-dimethylthiazol-2-yl)-2,5-diphenyltetrazolium bromide (MTT) Cell Proliferation and Cytotoxicity assay kit, 3-methyladenine (3-MA), monodansylcadaverine (MDC) Autophagy Detection kit, and annexin V-allophycocyanin (APC)/7-aminoactinomycin D (7-AAD) Apoptosis Detection kit were purchased from Sigma-Aldrich (Merck Millipore, Darmstadt, Germany). Fetal bovine serum (FBS), Hoechst 33,342/propidium iodide (PI) Double Staining kit, TRIzol ${ }^{\circledR}$ reagent, First-Strand cDNA Synthesis kit and Taq DNA Polymerase were purchased from Thermo Fisher Scientific, Inc. (Waltham, MA, USA). Bradford Protein Content assay kit (cat. no. KGA801), SDS-PAGE Gel Preparation kit (cat. no. KGP113), Coomassie Blue Staining kit (cat. no. KGP1001), Ponceau S staining solution (cat. no. KGP105) and glyceraldehyde-3-phosphate dehydrogenase (GAPDH) were obtained from Nanjing KeyGen Biotech Co., Ltd. (Nanjing, China).

Cell culture. The DU145 human prostate cancer cell line was obtained from Nanjing KeyGen Biotech Co., Ltd. The cells were cultured in MEM containing $10 \% \mathrm{FBS}$ at $37^{\circ} \mathrm{C}$ in a $5 \%$ $\mathrm{CO}_{2}$ incubator. Cells in the logarithmic growth phase were used for subsequent experiments.

MTT assay of cell proliferation $\left(I C_{50}\right)$. A cell suspension of $5 \times 10^{4}$ cells $/ \mathrm{ml}$ was prepared, and $100 \mu \mathrm{l}$ of this was added to each well of a 96-well culture plate, which was incubated at $37^{\circ} \mathrm{C}$ in a $5 \% \mathrm{CO}_{2}$ incubator for $24 \mathrm{~h}$. Complete medium was used to dilute diosgenin to the desired concentrations $(100,50$, $25,12.5,6.25,3.125,1.5625,0.78125$ and $0.1953125 \mu \mathrm{g} / \mathrm{ml})$, and $100 \mu \mathrm{l}$ of the corresponding diosgenin-containing medium was added per well. 3-MA was added to cells at a final concentration of $5 \mathrm{nM}$. Untreated cells were the negative control group, while cells treated with $10 \mu \mathrm{g} / \mathrm{ml}$ paclitaxel were the positive control group. The 96-well plate was incubated at $37^{\circ} \mathrm{C}$ in a $5 \% \mathrm{CO}_{2}$ incubator for $48 \mathrm{~h}$. The plate was then subjected to MTT staining, according to the procedures described previously (32), and the optical density of the samples was measured at a wavelength of $490 \mathrm{~nm}$. The inhibition rate and $\mathrm{IC}_{50}$ value of each group were calculated using the following formula: Inhibition rate $(\%)=[($ Negative control group - Experimental group) / Negative control group] x 100 .

Annexin-V APC/7-AAD double staining to detect apoptosis. Cells growing in the logarithmic phase were trypsinized and seeded at a density of $5 \times 10^{4}$ cells/well in a 6 -well plate. The following day, once cells had adhered to the plate, the corresponding diosgenin-containing medium was added (0.6, 3 or $15 \mu \mathrm{g} / \mathrm{ml})$. A negative control group, consisting of untreated cells was included. Following incubation for $48 \mathrm{~h}$ at $37^{\circ} \mathrm{C}$ and $5 \% \mathrm{CO}_{2}, 0.25 \%$ trypsin [without ethylenediaminetetraacetic acid (EDTA)] was used to remove the cells. The cells were washed twice with phosphate-buffered saline (PBS) and centrifuged at $447.2 \mathrm{x} \mathrm{g}$ for $5 \mathrm{~min}$ at $20^{\circ} \mathrm{C}$. A total of $5 \times 10^{5}$ cells were resuspended in $500 \mu \mathrm{l}$ binding buffer, following which $5 \mu$ l of annexin V-APC was added and mixed well, and $5 \mu 1$ 7-AAD was added and mixed well. The reaction was performed at room temperature for 5-15 min in the dark, and a flow cytometer (FACSCalibur; BD Biosciences, Franklin Lakes, NJ, USA), together with the BD CellQuest software (BD Biosciences) was used to detect apoptosis.

Transmission electron microscopy. DU145 cells $\left(1 \times 10^{5}\right.$ cells $\left./ \mathrm{ml}\right)$ in the logarithmic growth phase were incubated in diosgenin-containing medium $(15,3$ or $0.6 \mu \mathrm{g} / \mathrm{ml})$. A negative control group consisting of untreated cells was included. Cells were harvested $24 \mathrm{~h}$ later, using trypsin $(0.25 \%)$ to remove the cells from the plate. Cells were then centrifuged at $111.8 \times \mathrm{g}$ for $10 \mathrm{~min}$ at $20^{\circ} \mathrm{C}$. The supernatants were discarded, cells were washed twice with PBS and $2.5 \%$ glutaric acid was added. The cells were fixed for $90 \mathrm{~min}$ at $4^{\circ} \mathrm{C}$ and then embedded, sectioned and stained with uranyl acetate and lead citrate. Autophagosomes were observed under a transmission electronic microscope (JEM-1011; JEOL, Ltd., Tokyo, Japan).

MDC staining to detect autophagy. Cells in the logarithmic growth phase were trypsinized and seeded into a 6-well plate at a density of $5 \times 10^{5} \mathrm{cell} / \mathrm{ml} / \mathrm{well}$. The following day, once cells had adhered, diosgenin-containing medium was added $(15,3$ or $0.6 \mu \mathrm{g} / \mathrm{ml})$. A negative control group consisting of untreated cells was included. Cells were harvested using $0.25 \%$ trypsin (without EDTA) following a 48-h incubation. Wash buffer $(1 \mathrm{X} ; 300 \mu \mathrm{l})$ was used to wash the cells once, and cells were then resuspended in $1 \mathrm{X}$ wash buffer at $1 \times 10^{6}$ cells $/ \mathrm{ml}$. A total of $90 \mu \mathrm{l}$ of cell suspension was transferred to a new microfuge tube, and $10 \mu \mathrm{l}$ of MDC staining solution was added and gently mixed. Following staining at room temperature for 15-45 min in the dark, cells were collected by centrifugation at $800 \mathrm{x} g$ for $5 \mathrm{~min}$. The cells were washed three times with wash buffer and resuspended in $100 \mu \mathrm{l}$ of collection buffer. The cell suspension was dropped onto a slide and covered with a coverslip. Cells were observed under a fluorescence microscope (IX51; Olympus Corporation, Tokyo, Japan).

Western blotting to determine protein expression levels. Cells in the logarithmic growth phase were trypsinized and seeded onto a 6 -well plate at a density of $5 \times 10^{5}$ cell $/ \mathrm{ml} /$ well. 
The following day, once cells had adhered to the plate, diosgenin-containing medium was added $(15,3$ or $0.6 \mu \mathrm{g} / \mathrm{ml})$. A negative control group consisting of untreated cells was included. Pre-chilled lysis buffer $(200 \mu \mathrm{l})$, consisting of $20 \mathrm{nM}$ Tris (pH 7.5), 150 mM NaCl, Triton-X-100 (cat. no. KGP701; KayGen Biotech, Co., Ltd), was added to each group and incubated on ice for $30 \mathrm{~min}$. Following vortexing, the lysate was centrifuged at $13,000 \times \mathrm{g}$ for $10 \mathrm{~min}$ at $4^{\circ} \mathrm{C}$. The supernatant was retained, and the Bradford Protein Content assay kit was used to measure the protein concentration of the samples. Proteins $(30 \mu \mathrm{g})$ were resolved on a $10 \%$ SDS-PAGE gel and transferred to a polyvinylidene difluoride membrane. Following blocking overnight with 5\% non-fat milk, the membranes were incubated overnight at $4^{\circ} \mathrm{C}$ in a sealed bag with the following primary antibodies: Mouse anti-human light chain 3 (LC3)-I (cat. no. KGATG007; dilution, 1:500); mouse anti-human LC3-II (cat. no. KGATG007; dilution, 1:500); rabbit anti-human phosphatidylinositol 3 kinase (PI3K; cat. no. KG22639; dilution, 1:500); rabbit anti-human phosphorylated (p)-PI3K (cat. no. KG22638-2; dilution, 1:500); rabbit anti-human protein kinase B (Akt; cat. no. KG21502; dilution, 1:200); rabbit anti-human p-Akt (cat. no. KG11054-2; dilution, 1:200); rabbit anti-human mammalian target of rapamycin (mTOR; Ser 2448; cat. no. KGYT2914-7; dilution, 1:200); rabbit anti-human p-mTOR (cat. no. KGYP0176-6; dilution, 1:200); and anti-GAPDH (cat. no. KGAA002-2; dilution, 1:200). All primary antibodies were obtained from KayGen Biotech Co., Ltd. Tris-buffered saline and Tween 20 was used to wash the membrane three times for $10 \mathrm{~min}$ before it was incubated with horseradish peroxidase-conjugated goat anti-mouse IgG (cat. no. KGAA37; dilution, 1:4,000) or goat anti-rabbit IgG (cat. no. KGAA35; dilution, 1:4,000; both from KayGen Biotech, Co., Ltd.) secondary antibodies for $1 \mathrm{~h}$ at $37^{\circ} \mathrm{C}$. Finally, the membrane was visualized using an enhanced chemiluminescence method (cat. no. KGP1201; KayGen Biotech Co., Ltd.) and exposed to film. Protein band densities were quantified using Quantity One analysis software (version, V4.4.0.36; Bio-Rad, Inc., Hercules, CA, USA).

Hoechst 33,342/PI double staining to detect apoptosis. Cells in the logarithmic growth phase were trypsinized and seeded into a 6 -well plate at a density of $1 \times 10^{5}$ cell $/ \mathrm{ml} /$ well. The following day, once cells had adhered, diosgenin-containing medium was added. A negative control group consisting of untreated cells was included. Cells were harvested with $0.25 \%$ trypsin (without EDTA) following incubation for $48 \mathrm{~h}$. Cells $\left(10^{5}-10^{6}\right)$ were resuspended in $1 \mathrm{ml}$ of medium and $10 \mu \mathrm{l}$ Hoechst 33,342 staining solution was added to the cells and incubated at $37^{\circ} \mathrm{C}$ for 5-15 min. The cells were centrifuged at $111.8 \times \mathrm{g}$ for $5 \mathrm{~min}$ at $4^{\circ} \mathrm{C}$, and the supernatant was discarded. Buffer $\mathrm{A}(1 \mathrm{ml})$ was used to resuspend the cells, and $5 \mu \mathrm{l}$ PI staining solution was added and incubated at room temperature for 5-15 $\mathrm{min}$ in the dark. The suspension was mixed well and observed under a fluorescence microscope. The number of apoptotic cells was determined by counting the number of PI-positive cells in 3 random fields of view for each sample.

Reverse transcription-quantitative polymerase chain reaction (RT-qPCR) to detect gene expression. Pre-cooled TRIzol
(1 ml) was added to DU145 cells $\left(1 \times 10^{6}\right)$ growing in logarithmic phase, and the solution was repeatedly retro-pipetted until it was transparent. The solution was then transferred to a $1.5 \mathrm{ml}$ centrifuge tube, and incubated at room temperature for $5 \mathrm{~min}$. Chloroform $(0.2 \mathrm{ml})$ was subsequently added and the cover was fastened. The tube was shaken for $15 \mathrm{~s}$ until the solution was white in color, before it was incubated at room temperature for $3 \mathrm{~min}$. The solution was then centrifuged at $16099.2 \times \mathrm{g}$ for $15 \mathrm{~min}$ at $4^{\circ} \mathrm{C}$, before $0.6 \mathrm{ml}$ of the supernatant was transferred to a fresh centrifuge tube. Ispropyl alcohol $(0.6 \mathrm{ml})$ was subsequently added and, after gentle vortexing, the sample was incubated at room temperature for $10 \mathrm{~min}$ and centrifuged at $16099.2 \times \mathrm{g}$ for $10 \mathrm{~min}$ at $4^{\circ} \mathrm{C}$. The supernatant was removed and $1 \mathrm{ml} 70 \%$ ethanol was added along the tube wall, before it was vortexed gently and centrifuged at $16099.2 \times \mathrm{g}$ for $10 \mathrm{~min}$ at $4^{\circ} \mathrm{C}$. The supernatant was removed, air-dried and precipitated at room temperature for approximately $5 \mathrm{~min}$, before 30-50 $\mu \mathrm{l}$ RNase-free water was added to dissolve the RNA precipitate. Following complete dissolution, the solution was preserved at $-70^{\circ} \mathrm{C}$ until required. The RNA was reverse transcribed into cDNA using the First Strand cDNA Synthesis kit (Thermo Fisher Scientific, Inc.), and RT-qPCR was performed using SYBR Green Realtime PCR Master Mix (cat. no. QPK-201; Toyobo, Co., Ltd., Osaka, Japan) and the StepOnePlus software program (version 2.0; Applied Biosystems; Thermo Fisher Scientific, Inc.). The primers were synthesized by Gen Script (Nanjing) Co., Ltd. (Nanjing, China) and had the following sequences: Sense, 5'-ACAACTTTGGTATCGTGGAAGG-3' and antisense, 5'-GCCATCACGCCACAGTTTC-3' for GAPDH (101 bp); sense, 5'-ATGTCCACAGAAAGTGCCAA-3' and antisense, 5'-GGGTGATCCACATCTGTCTG-3' for Beclin 1 (140 bp); and sense, 5'-AAATCCGACCACTAATTGCC-3' and antisense, 5'-TGCTCTTCAGATGGTGATCC-3' for B-cell lymphoma $2(\mathrm{Bcl} 2 ; 114 \mathrm{bp})$. The amplification conditions were $95^{\circ} \mathrm{C}$ pre-denaturation for $5 \mathrm{~min}$ followed by 40 cycles of $95^{\circ} \mathrm{C}$ denaturation for $15 \mathrm{sec}, 60^{\circ} \mathrm{C}$ annealing for $20 \mathrm{sec}$, and $72^{\circ} \mathrm{C}$ extension for $40 \mathrm{sec}$. The specificity of the amplified products was monitored by melting curves. ABI StepOne software (version, 2.3; Applied Biosystems; Thermo Fisher Scientific, Inc.) was used to calculate the relative expression (using $2^{-\Delta \Delta \mathrm{Cq}}$ ) of the target genes in each group, and GAPDH served as an internal reference to assess the expression of target genes (33).

Statistical analysis. All data are presented as the mean \pm standard deviation. Statistical analyses were performed in SPSS software version 16.0 (SPSS, Inc., Chicago, IL, USA). Analysis of variance was used to compare differences between groups. $\mathrm{P}<0.05$ was considered to indicate a statistically significant difference.

\section{Results}

Inhibitory effect of diosgenin on the proliferation of DU145 cells. DU145 cells were treated with diosgenin (100, 50, 25, $12.5,6.25,3.125,1.5625,0.78125$ or $0.1953125 \mu \mathrm{g} / \mathrm{ml}$ ) for $48 \mathrm{~h}$. Diosgenin inhibited DU145 cell proliferation in a dose-dependent manner (Fig. 1). At $48 \mathrm{~h}$, the $\mathrm{IC}_{50}$ was $6.757 \mu \mathrm{g} / \mathrm{ml}$, therefore $0.6,3$ and $15 \mu \mathrm{g} / \mathrm{ml}$ diosgenin concentrations were used for subsequent experiments. 
Effect of diosgenin on the apoptosis of DU145 cells. To assess whether the inhibition of proliferation by diosgenin was associated with apoptosis, DU145 cells were treated with diosgenin for $48 \mathrm{~h}$, and the percentage of apoptotic cells was analyzed by flow cytometry. Diosgenin induced apoptosis in DU145 cells in a dose-dependent manner $(\mathrm{P}<0.01$ for $0.6,3$ and $15 \mu \mathrm{g} / \mathrm{ml}$ diosgenin; Fig. 2).

Effect of diosgenin on the microstructural morphology of DU145 cells. To verify whether the cytoplasmic vacuoles observed by inverted microscopy were associated with autophagy, transmission electron microscopy was used to observe autophagosomes in DU145 cells treated with diosgenin. As presented in Fig. 3, untreated cells contained normal nuclei, cytoplasm, and organelles, whereas diosgenin-treated cells exhibited a large number of autophagosomes of various sizes. In addition, autophagosomes containing mitochondria were observed. This suggests that autophagy occurred in the cells following diosgenin treatment.

MDC staining of autophagosomes. MDC-labeled autophagic vacuoles were observed under an inverted fluorescence microscope and exhibited clear vesicles in the cytoplasm and perinuclear region, and the changes of the particles inside the cell were used to determine the level of autophagy. As presented in Fig. 4, diosgenin-treated cells exhibited increased fluorescence intensity and numbers of autophagic vacuoles compared with the control group. The number and staining intensity of the vacuoles increased in a dose-dependent manner. This suggests that diosgenin induces autophagy.

Diosgenin induces microtubule-associated protein $1 A / 1 B-L C 3$ and caspase 9 protein expression in DU145 cells. Western blotting was used to detect changes in the protein expression levels of LC3 and caspase 9 following treatment of DU145 cells with diosgenin. On SDS-PAGE gels, LC3-II ran faster than LC3-I, producing two bands by western blot. Fig. 5A indicates that untreated cells exhibited only a faint LC3-I band, whereas LC3-II was not detected. By contrast, following treatment with diosgenin, the protein expression levels of LC3-II increased significantly in a dose-dependent manner $(0.6 \mu \mathrm{g}, \mathrm{P}=0.006 ; 3 \mu \mathrm{g}, \mathrm{P}<0.001 ; 15 \mu \mathrm{g}, \mathrm{P}<0.001$; Fig. 5A). In addition, diosgenin treatment significantly increased the protein expression levels of caspase 9 compared with the control group, in a dose-dependent manner $(0.6 \mu \mathrm{g} / \mathrm{ml}, \mathrm{P}<0.001 ; 3 \mu \mathrm{g} / \mathrm{ml}, \mathrm{P}=0.002 ; 15 \mu \mathrm{g} / \mathrm{ml}$, $\mathrm{P}<0.001$; Fig. 5B).

Effect of diosgenin on the PI3K/Akt/mTOR signaling pathway. The PI3K/Akt/mTOR signaling pathway is the canonical pathway that negatively regulates the initiation of autophagy. It has been reported that inhibition of this signaling pathway induces cell autophagy. As presented in Fig. 6, western blotting demonstrated that diosgenin inhibited the phosphorylation of PI3K, Akt, and mTOR in the $\mathrm{PI} 3 \mathrm{~K} / \mathrm{Akt} / \mathrm{mTOR}$ signaling pathway.

Inhibition of autophagy increases the cytotoxicity of diosgenin. Preliminary experiments determined that diosgenin treatment induced autophagy and apoptosis in DU145 cells

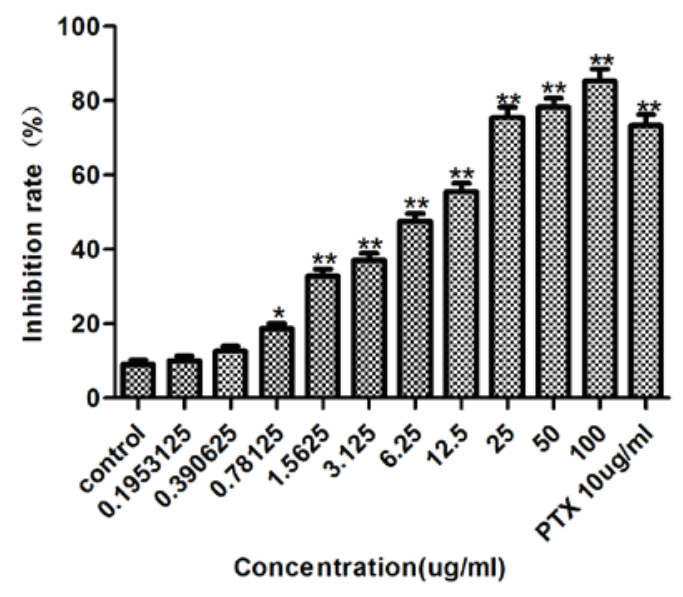

Figure 1. Concentration curve of the inhibition of DU145 cell proliferation by diosgenin. DU145 cells were treated with a range of concentrations of diosgenin for $48 \mathrm{~h}$. A dose-dependent inhibition of cell proliferation was observed. Data are expressed as the mean \pm standard deviation $(n=6)$. $P<0.05$ and ${ }^{* *} \mathrm{P}<0.01$ vs. control. PTX, paclitaxel.

and that the inhibition of DU145 proliferation by diosgenin occurred in a dose-dependent manner. To determine whether the cytotoxicity exhibited by diosgenin was mediated by autophagy, the autophagy inhibitor 3-MA was used, and MTT assays were performed to assess cytotoxicity. Compared with cells treated with diosgenin alone, the addition of 3-MA increased the percentage of non-viable DU145 cells $(\mathrm{P}<0.01$; Fig. 7).

Hoechst 33342 and PI double fluorescence staining of live cells. Hoechst 33342 and PI double staining distinguish live and dead cells. The nuclei of cells in the late apoptotic or early necrotic stages stain red, whereas the nuclei of live cells stain blue. No significant differences in the percentages of apoptotic cells were observed between control cells (Fig. 8A) and cells treated with 3-MA alone (Fig. 8B). However, cells treated with diosgenin (Fig. 8C) for $48 \mathrm{~h}$ exhibited nuclei with a bead-like shape, forming apoptotic bodies. Diosgenin treatment increased the percentage of apoptotic cells compared with control cells. Cells treated with diosgenin and 3-MA (Fig. 8D) exhibited an increased percentage of apoptotic cells compared with cells treated with diosgenin alone. These results demonstrated that apoptosis increased significantly following the inhibition of diosgenin-induced autophagy.

Effect of diosgenin on apoptosis following the inhibition of autophagy. As cytotoxicity of diosgenin was increased following the inhibition of autophagy, it was investigated whether autophagy inhibited the effect of diosgenin on apoptosis. RT-qPCR was performed to analyze mRNA expression levels in DU145 cells treated with diosgenin. Using Beclin 1 and $\mathrm{Bcl} 2$ as markers, the effect of diosgenin on autophagy and apoptosis was examined following the inhibition of autophagy. As presented in Fig. 9, following treatment with $5 \mathrm{mM} 3-\mathrm{MA}$ alone, the mRNA expression levels of Beclin 1 decreased compared with the control cells. Following treatment with $6.8 \mu \mathrm{g} / \mathrm{ml}$ diosgenin, the mRNA expression levels of Beclin1 increased significantly compared with 
$\mathbf{A}$
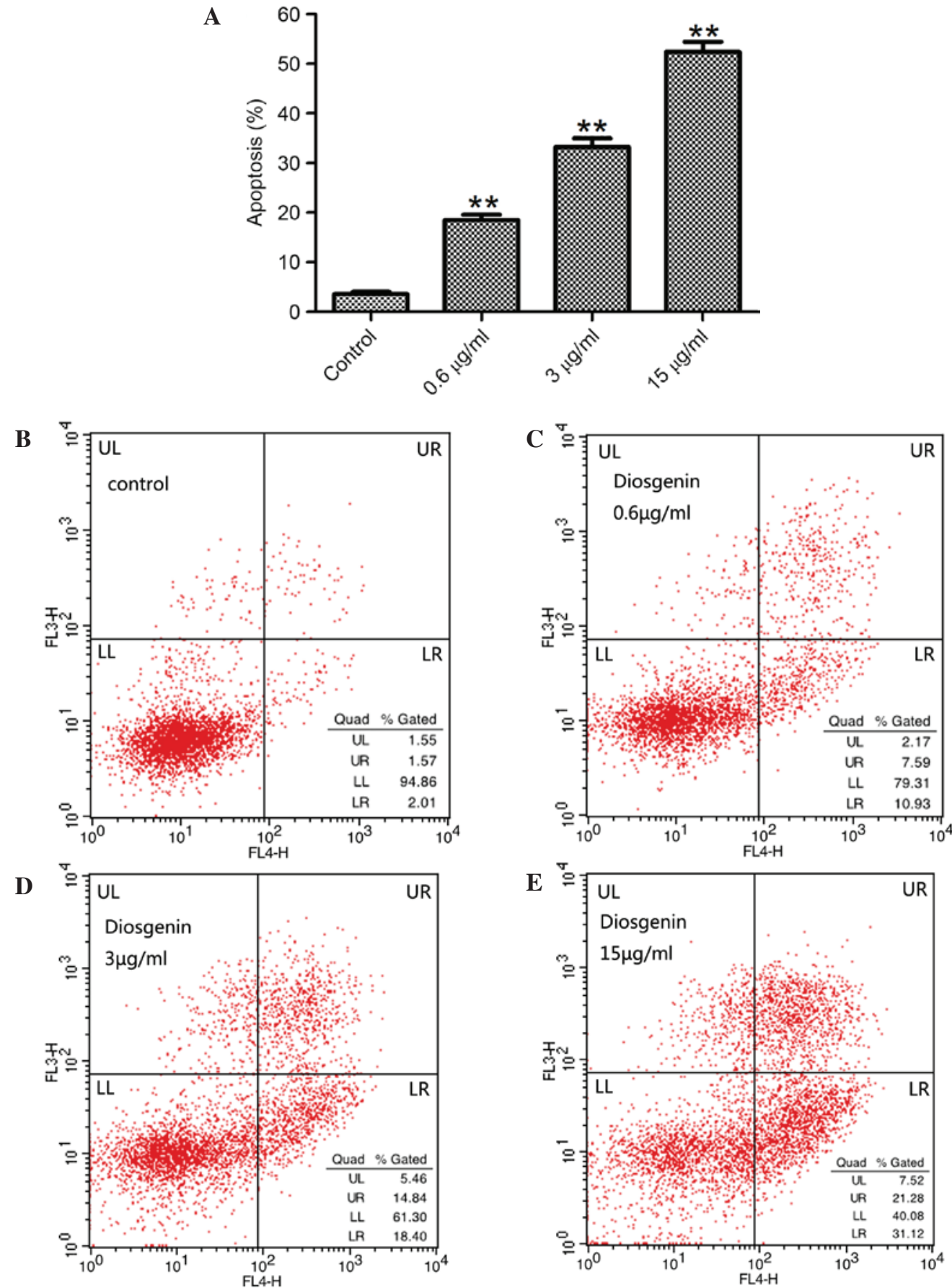

Figure 2. Concentration curve of the apoptosis of DU145 cells by diosgenin. (A) Compared with the control group, (A) the percentage of apoptotic cells in the diosgenin group increased significantly and in a dose-dependent manner. The data are expressed as the mean \pm standard deviation $(\mathrm{n}=3){ }^{* *} \mathrm{P}<0.01 \mathrm{vs}$. control group. Fluorescence-activated cell sorting plots showing the number of apoptotic cells in UR and LR quadrants following treatment with (B) 0, (C) 0.6, (D) 3 and (E) $15 \mu \mathrm{g} / \mathrm{ml}$ diosgenin. UR, late apoptosis; LR, early apoptosis.

control cells $(\mathrm{P}<0.01)$. However, when diosgenin was added following simultaneous treatment with 3 -MA, Beclin 1 mRNA expression levels significantly decreased compared with cells treated with diosgenin alone $(\mathrm{P}<0.01)$. Following treatment with diosgenin alone, Bcl2 mRNA expression levels decreased significantly compared with control cells $(\mathrm{P}<0.01)$. Simultaneous treatment with $3-\mathrm{MA}$ significantly decreased Bcl 2 mRNA expression levels compared with cells treated with diosgenin alone $(\mathrm{P}<0.01)$. These results suggest that when autophagy was inhibited, the apoptotic effect of diosgenin was increased.

\section{Discussion}

The results of the MTT assay indicated that diosgenin significantly inhibits the proliferation of DU145 cells in a dose-dependent manner, suggesting that diosgenin induces DU145 cell death.

Apoptosis is an important pathway of cell death. Therefore, flow cytometry was performed in the present study to detect the effect of diosgenin on apoptosis. The results demonstrated that the percentage of apoptotic diosgenin-treated cells increased significantly in a dose-dependent manner, suggesting that 

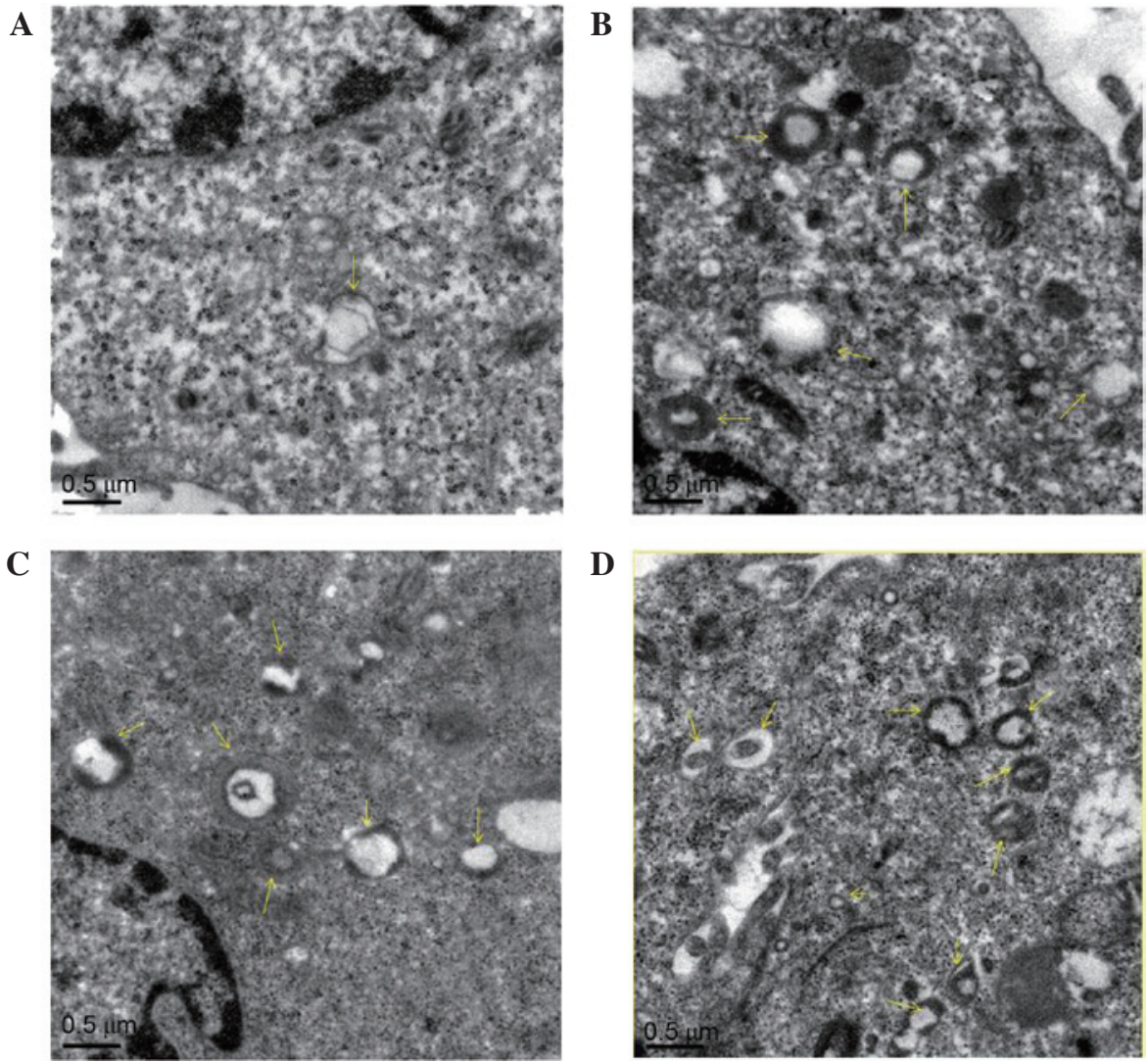

Figure 3. Observation of the microstructure of DU145 cells treated with diosgenin. (A) Untreated DU145 cells had a normal nucleus, cytoplasm, and organelle morphology. Cells treated with (B) 0.6 , (C) 3 and (D) $15 \mu \mathrm{g} / \mathrm{ml}$ diosgenin exhibited a large number of autophagic vacuoles of various sizes, and certain autophagosomes contained mitochondria and cytoplasm. Magnification, x20,000). Arrows indicate autophagic vacuoles and autophagosomes.

A

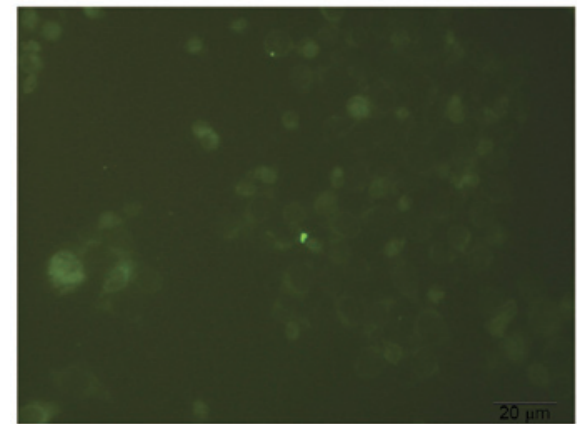

C

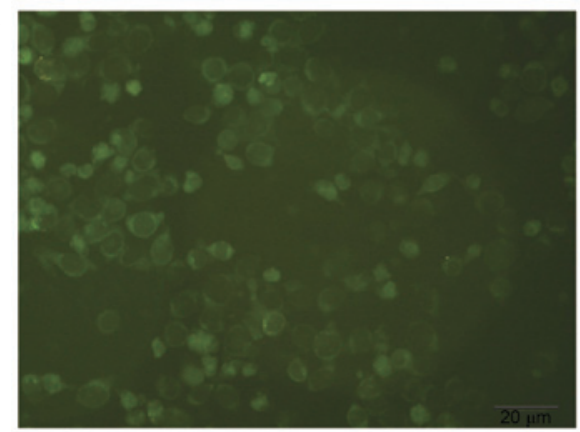

B

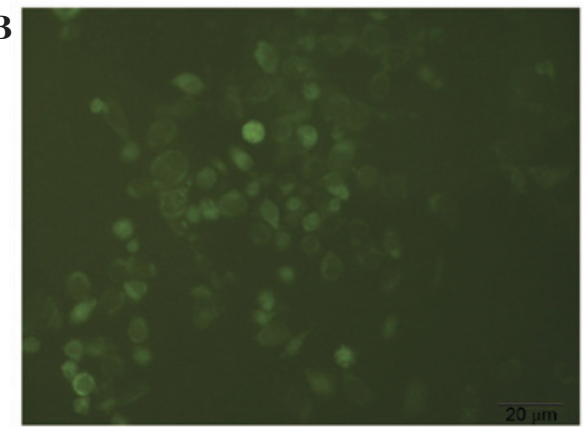

D

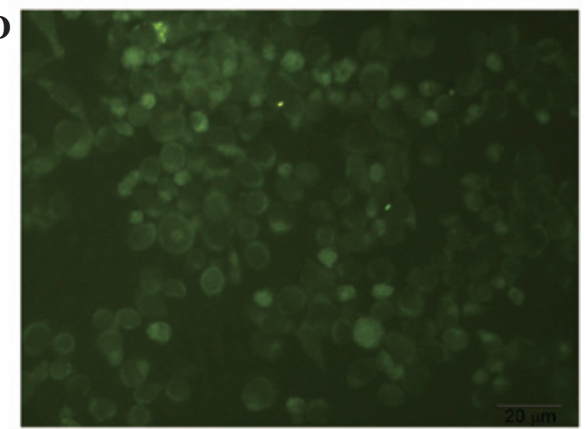

Figure 4. Autophagic vacuoles in DU145 cells labeled with MDC. Compared with (A) the control group cells treated with (B) 0.6 , (C) 3 and (D) $15 \mu$ g/ml diosgenin exhibited increased number and fluorescence intensity of autophagic vacuoles labeled with MDC. Magnification, x100. MDC, monodansylcadaverine.

diosgenin inhibits proliferation by promoting apoptosis in tumor cells.

Apoptosis is a complex physiological process that involves numerous genes, in which the caspase family is important.
Caspase 9 is a cysteine protease that uses aspartic acid as a substrate and is a core component of the apoptotic pathway (34). Caspase 9 is the most important initiator of the endogenous apoptotic pathway and is an upstream initiating caspase that 
A

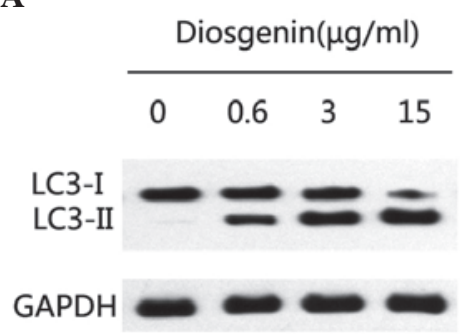

B

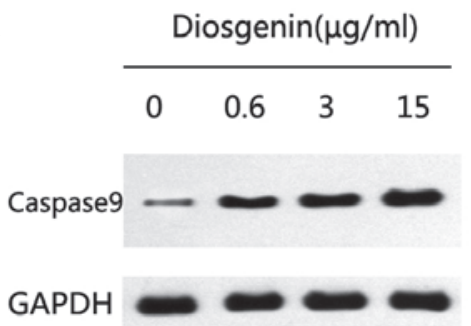

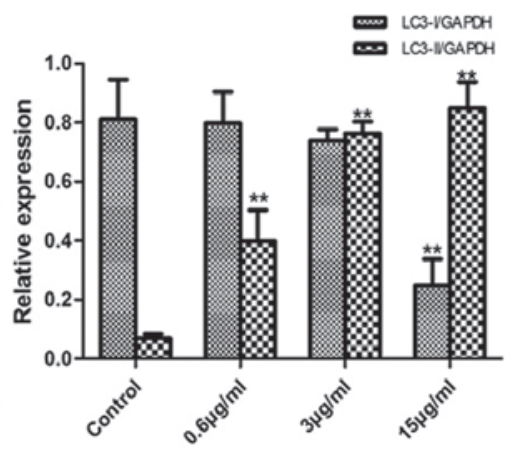

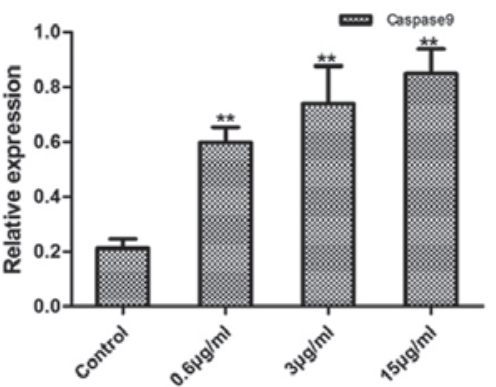

Figure 5. Diosgenin induces the expression of LC3 and caspase 9 in DU145 cells. Western blot detection of the protein expression levels of (A) LC3-I and LC-II and (B) caspase 9 in DU145 cells treated with various concentrations of diosgenin. ${ }^{* *} \mathrm{P}<0.01$ vs. controls. LC3, microtubule-associated protein $1 \mathrm{~A} / 1 \mathrm{~B}-\mathrm{light}$ chain 3.

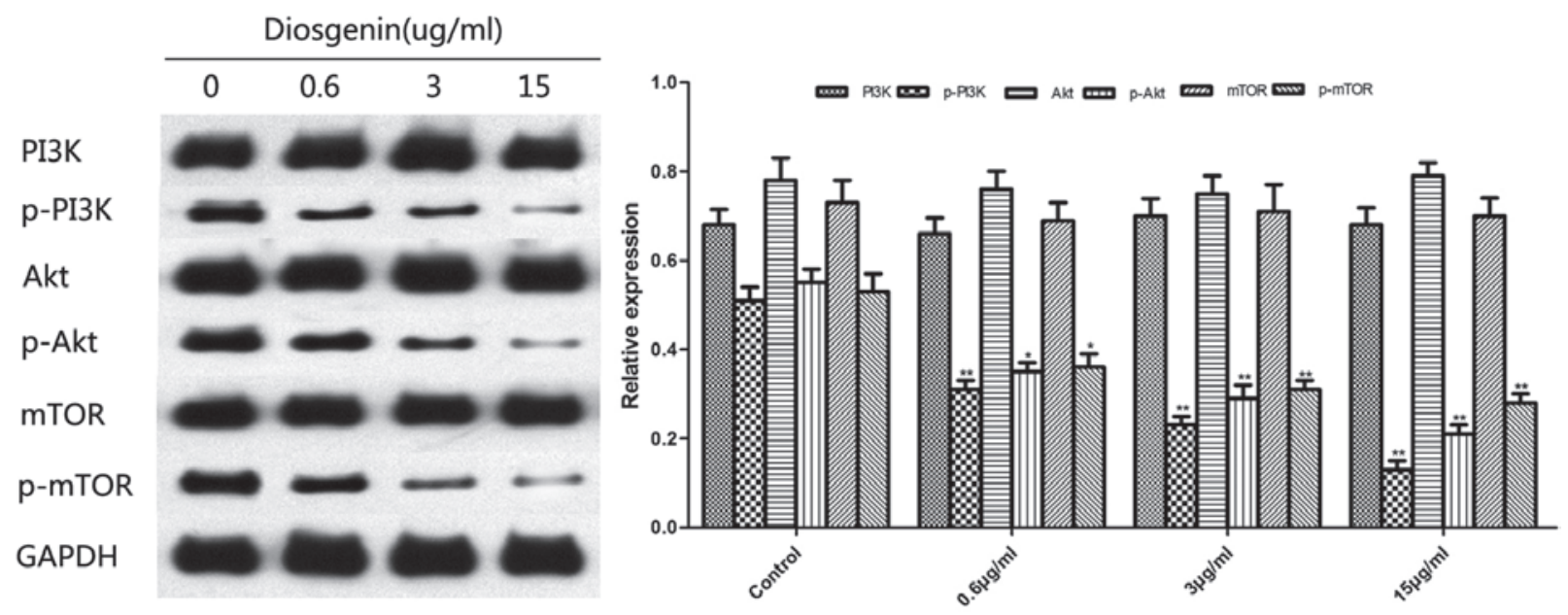

Figure 6. Effect of diosgenin on the PI3K/Akt/mTOR signaling pathway. Following diosgenin treatment, no differences were observed in the protein expression levels of PI3K, Akt and mTOR; however, the phosphorylation of PI3K, Akt and mTOR decreased significantly, in a dose-dependent manner. * $<0.05$ and ${ }^{* *} \mathrm{P}<0.01$ vs. controls. PI3K, phosphatidylinositol 3 kinase; Akt, protein kinase B; mTOR, mammalian target of rapamycin; p, phosphorylated.

activates downstream factors of apoptosis, initiates cascade activation reactions, and inactivates proteins that regulate cell structure, cell cycle and DNA repair, resulting in the initiation of apoptosis (35-37). The present study determined the protein expression levels of caspase 9 in DU145 cells by western blotting. The results indicated that the expression of caspase 9 significantly increased in cells treated with diosgenin, which further supports the induction of apoptosis by diosgenin.

Autophagy is a cell death process that is distinct from apoptosis. As a mechanism underlying cell defense and stress regulation, autophagy has been extensively investigated in cancer research. Autophagy refers to the process in eukaryotic cells in which a double membrane wraps around a portion of cytoplasm and the intracellular organelles and proteins to be degraded form an autophagosome. This fuses with endosomes to form an amphisome, which eventually fuses with lysosomes to form an autophagolysosome that degrades the packaged contents (38-41). Under physiological conditions, autophagy occurs at low levels. When cells are under various stress conditions, including insufficient nutrition, a lack of growth factors and hypoxia, cells initiate autophagy $(42,43)$, which is crucial for the maintenance of the stability of the intracellular environment and the normal physiological functions of the cell. Previous studies have demonstrated that autophagy is closely involved in the pathogenesis and progression of tumors. Autophagy inhibits tumor 
growth, particularly during the early stages of tumor formation; however, autophagy may lead to tumor cell adaptation to adverse metabolic stress and, thus, allow survival of tumor cells (44-46). In addition, numerous antitumor therapeutic agents induce autophagy; however, whether this results the death of tumor cells or instead promotes tumor cell survival remains controversial (47). Therefore, the present study performed transmission electronic microscopy to observe DU145 cells and determined that the cytoplasm of cells treated with diosgenin contained numerous autophagic vacuoles of various sizes. In addition, the formation of autophagosomes was observed, confirming that diosgenin induced autophagy. To verify this finding, MDC was used to stain for autophagic vacuoles. MDC is a fluorescent dye that is absorbed by cells and stains autophagic vacuoles. Fluorescence microscopy of MDC-labeled autophagic vacuoles identified vesicles in the cytoplasm and perinuclear region. The change in intracellular particles was used to determine the autophagy level. Compared with control cells, diosgenin-treated cells exhibited a greater fluorescence intensity and an increased number of MDC-labeled autophagic particles, suggesting that diosgenin induces autophagy.

LC3 is the homolog of the yeast protein Atg8 and serves as a marker of autophagy in mammalian cells (48). In tumor cells, LC3 may be processed to generate cytoplasmic LC3-I, which undergoes a ubiquitination-like modification of a covalent linkage to phosphatidylethanolamine on autophagosome membranes to form LC3-II $(49,50)$. Based on the observation that the level of LC3-II corresponds to the level of autophagy (51), the initiation of autophagy may be determined by the measurement of LC3-II protein expression levels. The present study performed western blotting to determine the protein expression levels of LC3-II, and the results revealed that the ratio of LC3-II/LC3-I in DU145 cells treated with diosgenin increased, further confirming that diosgenin induces autophagy in tumor cells.

The PI3K/Akt/mTOR signaling pathway is widely recognized to regulate cell proliferation, autophagy, apoptosis and motility, and is critical for the pathogenesis, progression and prognosis of cancer (52-54). Following PI3K activation, the second messengers phosphatidylinositol $(3,4,5)$-biphosphate and phosphatidylinositol $(3,4,5)$-triphosphate are generated at the cell membrane and in turn activate the downstream kinase Akt. Activated Akt is anti-apoptotic, promotes cell survival and performs other biological functions via the activation of downstream substrates (55). The downstream protein mTOR activates protein translation and promotes cell growth (56) and is a critical inhibitory factor of autophagy. Under normal growth conditions, mTOR is in an active state, and intracellular autophagy is inhibited. Under stress conditions, including insufficient nutrition, the activity of mTOR is inhibited to promote autophagy $(57,58)$. In addition, caspase 9 is a downstream target of the PI3K/Akt/mTOR signaling pathway. Akt reduces caspase 9 activity by phosphorylating S196 on the caspase 9 precursor protein, thus inhibiting apoptosis and promoting tumorigenesis (59). To further investigate the mechanism underlying diosgenin activity, western blotting was performed to determine the protein expression levels of members of the PI3K/Akt/mTOR signaling pathway. The results indicated that diosgenin significantly inhibited

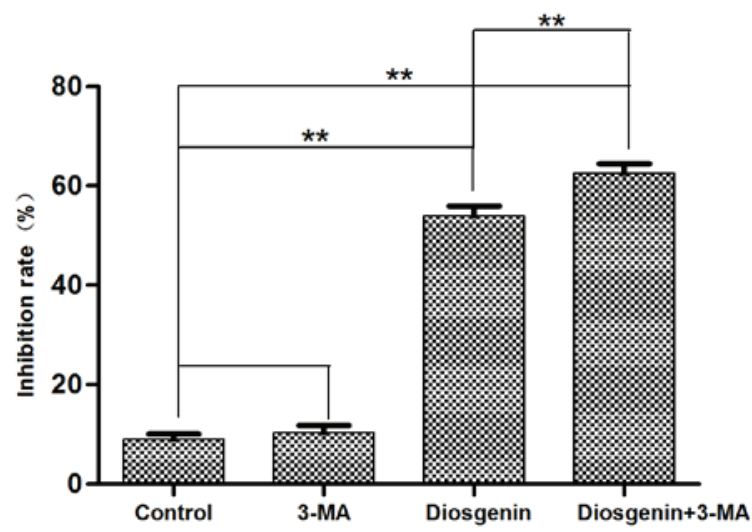

Figure 7. Effect of the inhibition of autophagy on diosgenin cytotoxicity. DU145 cells were pretreated with $5 \mathrm{mM} 3$-MA for $48 \mathrm{~h}$, and subsequently treated with $6.8 \mu \mathrm{g} / \mathrm{ml}$ diosgenin for $48 \mathrm{~h}$. MTT assays were performed to detect proliferation. The inhibition of cell proliferation by diosgenin following the addition of 3-MA was significantly increased compared with cells treated with diosgenin alone. Data are expressed as the mean \pm standard deviation $(n=6) .{ }^{* *} \mathrm{P}<0.01$ vs. controls or diosgenin-treated cells (as indicated) 3-MA, 3-methyladenine; MTT, 3-(4,5-dimethylthiazol-2-yl)-2,5-diphenyltetrazolium bromide.

the phosphorylation of PI3K, Akt, and mTOR, suggesting that diosgenin activates tumor cell autophagy and apoptosis potentially by inhibiting the PI3K/Akt/mTOR signaling pathway.

These results demonstrated that diosgenin inhibits the proliferation of DU145 cells and activates autophagy and apoptosis. Inhibition of the phosphorylation of members of the PI3K/Akt/mTOR signaling pathway is an underlying antitumor mechanisms of diosgenin.

To further verify the effect of autophagy on the induction of apoptosis by diosgenin, the autophagy inhibitor 3-MA was used in combination with diosgenin to treat DU145 cells. The results of the MTT assays demonstrated that the percentage of dead cells increased significantly following combined treatment. Hoechst 33342/PI live-cell staining demonstrated a significant increase in apoptosis of cells administered the combined treatment, suggesting that the inhibition of diosgenin-activated autophagy increases apoptosis to achieve increased antitumor effects.

RT-qPCR was performed to determine Beclin 1 and $\mathrm{Bcl} 2$ mRNA expression levels. Beclin 1 is the mammalian homolog of the yeast ATG6-Vps30 protein, which has a key regulatory role in tumorigenesis and autophagosome formation $(60,61) . \mathrm{Bcl} 2$ inhibits apoptosis (62) and interacts with Beclin 1. Beclin 1 is considered to induce autophagy, whereas Bcl2 inhibits Beclin 1-dependent autophagy $(63,64)$. Therefore, Bcl2/Beclin 1 signaling is an important regulator of autophagy. The results of the present study demonstrated that the mRNA expression levels of $\mathrm{Bcl} 2$ in cells treated with diosgenin decreased significantly, whereas the Beclin 1 mRNA expression levels increased significantly, confirming that diosgenin induces apoptosis and autophagy. Following the inhibition of autophagy, apoptosis increased significantly, consistent with the Hoechst 33342/PI staining result.

In conclusion, the results of the present study demonstrate that diosgenin has marked antitumor activity in the DU145 prostate cancer cell line. Diosgenin inhibits the proliferation 
A

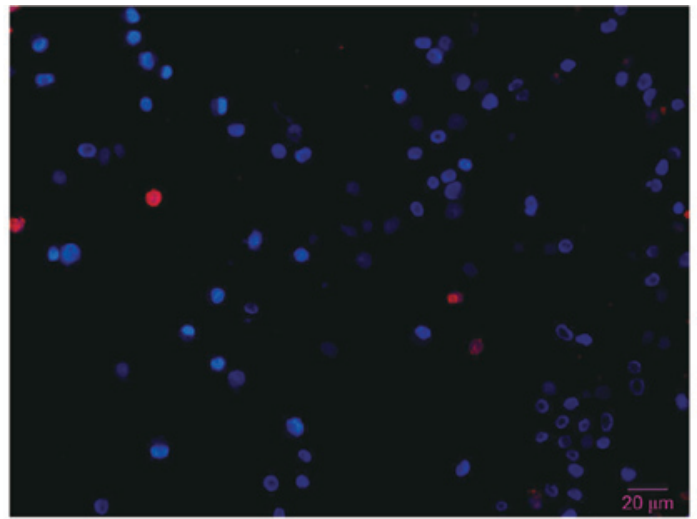

C

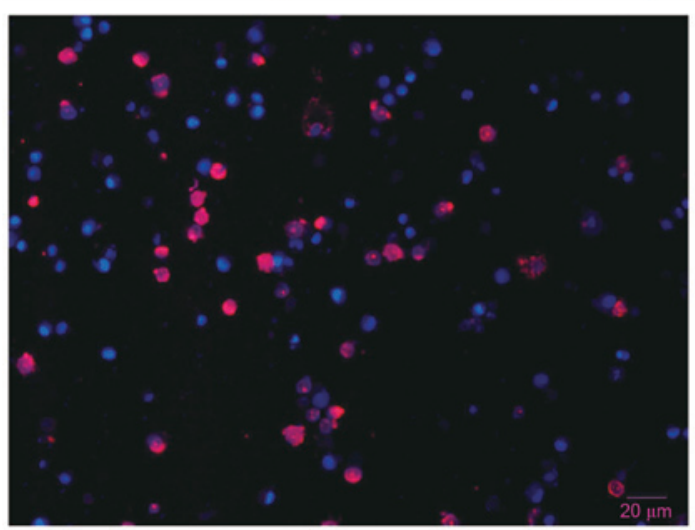

B

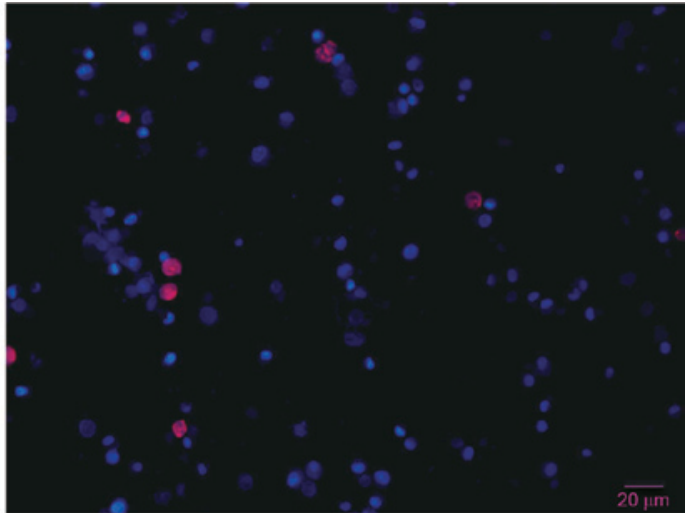

D

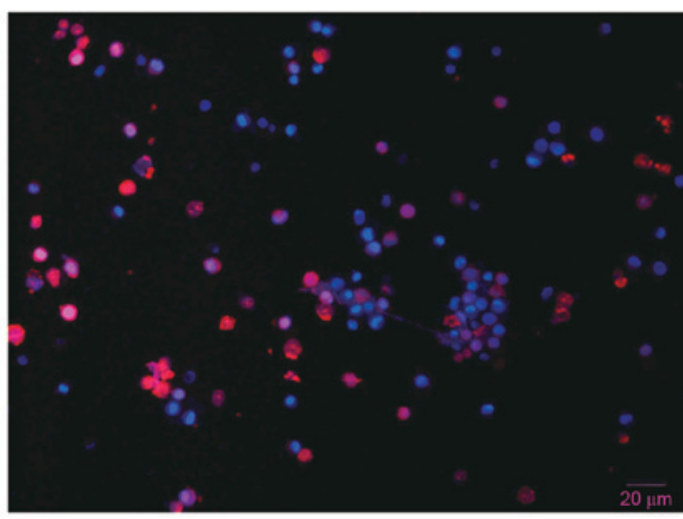

Figure 8. Hoechst and PI double fluorescence staining of DU145 cells. Representative fluorescence images of (A) untreated control DU145 cells and those treated with (B) 3MA, (C) diosgenin and (D) 3MA plus diosgenin. Following treatment with diosgenin for $48 \mathrm{~h}$, the nuclei of DU145 cells exhibited a bead-like shape, forming apoptotic bodies. The number of apoptotic cells increased following treatment with 3MA plus diosgenin, compared with diosgenin alone. PI, propidium iodide; 3-MA, 3-methyladenine.
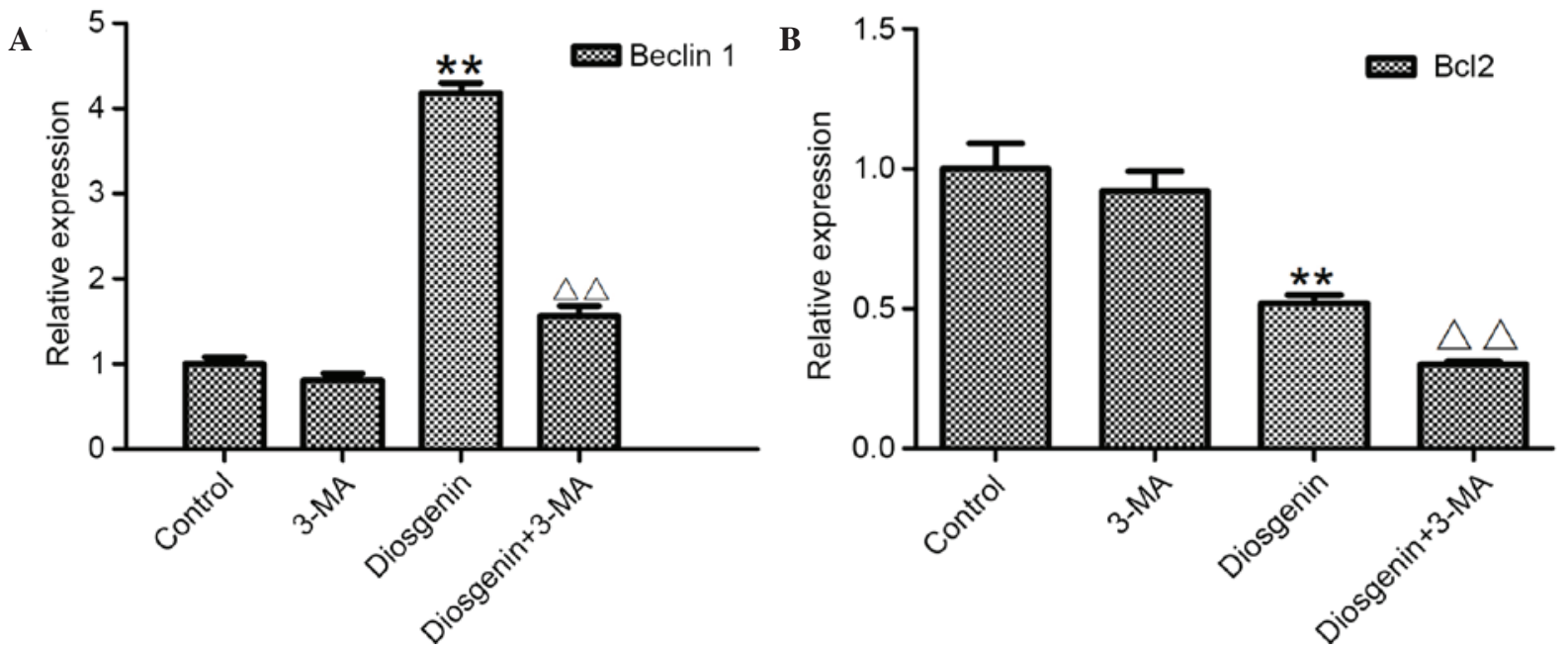

Figure 9. Effect of diosgenin on autophagy and apoptosis, following inhibition of autophagy. (A) Following treatment with 5 mM 3-MA alone, the mRNA expression levels of Beclin 1 was decreased compared with control cells. Following treatment with $6.8 \mu \mathrm{g} / \mathrm{ml}$ diosgenin, the mRNA expression levels of Beclin 1 increased significantly compared with control cells. However, when diosgenin was added following simultaneous treatment with 3-MA, Beclin 1 mRNA expression levels were significantly reduced compared with cells treated with diosgenin alone. (B) Following treatment with diosgenin, the mRNA expression levels of Bcl2 decreased significantly compared with control cells, whereas addition of 3-MA significantly decreased Bcl2 mRNA expression levels compared with cells treated with diosgenin alone. Data are expressed as the mean \pm standard deviation $(\mathrm{n}=3)$. ${ }^{* *} \mathrm{P}<0.01$ vs. control; ${ }^{\Delta \Delta} \mathrm{P}<0.01$ vs. diosgenin alone. 3 -MA, 3-methyladenine; Bcl2, B-cell lymphoma 2.

of DU145 cells by activating apoptosis and autophagy, and the mechanism underlying this activation may be associated with the inhibition of the PI3K/Akt/mTOR signaling pathway. In addition, the inhibition of autophagy mediated by diosgenin increases apoptosis and, thus, increases the therapeutic effect. The combination of diosgenin with an autophagy inhibitor may potentially be an effective strategy to further increase the antitumor effect of diosgenin. 


\section{Acknowledgements}

The present study was supported by the Health Department of Jiangsu Province (grant no. J201406) and Qing Lan Project.

\section{References}

1. Zhou CK, Check DP, Lortet-Tieulent J, Laversanne M, Jemal A, Ferlay J, Bray F, Cook MB and Devesa SS: Prostate cancer incidence in 43 populations worldwide: An analysis of time trends overall and by age group. Int J Cancer 138: 1388-1400, 2016.

2. Siegel R, Naishadham D and Jemal A: Cancer statistics, 2013. CA Cancer J Clin 63: 11-30, 2013.

3. Peskoe SB, Joshu CE, Rohrmann S, McGlynn KA, Nyante SJ, Bradwin G, Dobs AS, Kanarek N, Nelson WG and Platz EA: Circulating total testosterone and PSA concentrations in a nationally representative sample of men without a diagnosis of prostate cancer. Prostate 75: 1167-1176, 2015.

4. Glybochko PV, Aliaev IuG, Krupinov GE, Rapoport LM, Amosov AV, Bezrukov EA, Novichkov ND, Lachinov ÉL, Ganzha TM, Obukhov AA and Lerner IuV: Diagnosis and treatment of local recurrence of prostate cancer using hystoscanning and high-intensity focused ultrasound in patients after radical prostatectomy. Urologiia: 72-76, 2014 (In Russian).

5. Kelly BD, Miller N, Sweeney KJ, Durkan GC, Rogers E, Walsh K and Kerin MJ: A circulating MicroRNA signature as a biomarker for prostate cancer in a high risk group. J Clin Med 4: 1369-1379, 2015.

6. Bahl A, Hoefeler H, Duran I, Hechmati G, Garzon-Rodriguez C, Ashcroft J, Lorusso V, Ghelani P, Wei R, Thomas E and Lüftner D: Health resource utilization associated with skeletal-related events in patients with advanced prostate cancer: A European subgroup analysis from an observational, multinational study. J Clin Med 3:883-896, 2014.

7. Singh P, Pal SK, Alex A and Agarwal N: Development of PROSTVAC immunotherapy in prostate cancer. Future Oncol 11: 2137-2148, 2015.

8. Miyamae K, Kitani K, Hara K, Nakakuma K, Hamada Y, Yamasaki Y, Horio M and Miyamura S: Clinical study of long-term docetaxel based chemotherapy treatment for patients with castration-resistant prostate cancer. Nihon Hinyokika Gakkai Zasshi 105: 172-177, 2014.

9. Luo HC, Cheng HH, Lin GS, Fu ZC and Li DS: Intensitymodulated radiotherapy combined with endocrine therapy for intermediate and advanced prostate cancer: Long-term outcome of Chinese patients. Asian Pac J Cancer Prev 14: 4711-4715, 2013

10. Ishizaki F, Hara N, Takizawa I, Nishiyama T, Isahaya E, Kawasaki T and Takahashi K: Deficiency in androgens and upregulation of insulin-like growth factor-1 are involved in high bone turnover in men receiving androgen deprivation therapy for prostate cancer. Growth Horm IGF Res 22: 122-128, 2012.

11. Wang HQ, Jin JJ and Wang J: Matrine induces mitochondrial apoptosis in cisplatin-resistant non-small cell lung cancer cells via suppression of $\beta$-catenin/survivin signaling. Oncol Rep 33: 2561-2566, 2015.

12. Tuorkey MJ: Curcumin a potent cancer preventive agent: Mechanisms of cancer cell killing. Interv Med Appl Sci 6 : 139-146, 2014

13. Cheng X, Gu J, Zhang M, Yuan J, Zhao B, Jiang J and Jia X: Astragaloside IV inhibits migration and invasion in human lung cancer A549 cells via regulating PKC- $\alpha$-ERK1/2-NF- $\kappa B$ pathway. Int Immunopharmacol 23: 304-313, 2014.

14. Zhu X, Liu S, Zhou J, Wang H, Fu R, Wu X, Wang J and Lu F: Effect of Astragalus polysaccharides on chronic atrophic gastritis induce by N-methyl-N'-nitro-N-nitrosoguanidine in rats. Drug Res (Stuttg) 63: 597-602, 2013.

15. Ku SK, Kwak S and Bae JS: Orientin inhibits high glucose-induced vascular inflammation in vitro and in vivo. Inflammation 37: 2164-2173, 2014

16. Lucas CD, Dorward DA, Sharma S, Rennie J, Felton JM, Alessandri AL, Duffin R, Schwarze J, Haslett C and Rossi AG: Wogonin induces eosinophil apoptosis and attenuates allergic airway inflammation. Am J Respir Crit Care Med 191: 626-636, 2015.

17. Ma HD, Deng YR, Tian Z and Lian ZX: Traditional Chinese medicine and immune regulation. Clin Rev Allergy Immunol 44: 229-241, 2013.
18. Kim SG, Lee AJ, Bae SH, Kim SM, Lee JH, Kim MJ and Jang HB: Total extract of Korean red ginseng facilitates human bone marrow hematopoietic colony formation in vitro. Blood Res 49: 177-181, 2014.

19. Zhao L, Wang Y, Shen HL, Shen XD, Nie Y, Wang Y, Han T, Yin $M$ and Zhang QY: Structural characterization and radioprotection of bone marrow hematopoiesis of two novel polysaccharides from the root of Angelica sinensis (Oliv.) Diels. Fitoterapia 83: 1712-1720, 2012.

20. He Z, Chen H, Li G, Zhu H, Gao Y, Zhang L and Sun J: Diosgenin inhibits the migration of human breast cancer MDA-MB-231 cells by suppressing Vav2 activity. Phytomedicine 21: 871-876, 2014.

21. Yang HP, Yue L, Jiang WW, Liu Q, Kou JP and Yu BY: Diosgenin inhibits tumor necrosis factor-induced tissue factor activity and expression in THP-1 cells via down-regulation of the NF- $\kappa \mathrm{B}$, Akt, and MAPK signaling pathways. Chin J Nat Med 11: 608-615, 2013

22. Kalailingam P, Kannaian B, Tamilmani E and Kaliaperumal R: Efficacy of natural diosgenin on cardiovascular risk, insulin secretion, and beta cells in streptozotocin (STZ)-induced diabetic rats. Phytomedicine 21: 1154-1161, 2014.

23. Sato K, Fujita S and Iemitsu M: Acute administration of diosgenin or dioscorea improves hyperglycemia with increases muscular steroidogenesis in STZ-induced type 1 diabetic rats. J Steroid Biochem Mol Biol 143: 152-159, 2014.

24. McKoy ML, Thomas PG, Asemota H, Omoruyi F and Simon O: Effects of Jamaican bitter yam (Dioscorea polygonoides) and diosgenin on blood and fecal cholesterol in rats. J Med Food 17: 1183-1188, 2014.

25. Ebrahimi H, Badalzadeh R, Mohammadi M and Yousefi B: Diosgenin attenuates inflammatory response induced by myocardial reperfusion injury: Role of mitochondrial ATP-sensitive potassium channels. J Physiol Biochem 70: 425-432, 2014

26. Manivannan J, Shanthakumar J, Arunagiri P, Raja B and Balamurugan E: Diosgenin interferes coronary vasoconstriction and inhibits osteochondrogenic transdifferentiation of aortic VSMC in CRF rats. Biochimie 102: 183-187, 2014.

27. Badalzadeh R, Yousefi B, Majidinia M and Ebrahimi H: Anti-arrhythmic effect of diosgenin in reperfusion-induced myocardial injury in a rat model: Activation of nitric oxide system and mitochondrial KATP channel. J Physiol Sci 64: 393-400, 2014

28. Ghosh S, More P, Derle A, Kitture R, Kale T, Gorain M, Avasthi A, Markad P, Kundu GC, Kale S, et al: Diosgenin functionalized iron oxide nanoparticles as novel nanomaterial against breast cancer. J Nanosci Nanotechnol 15: 9464-9472, 2015.

29. Ding W, Jiang Y, Jiang Y, Zhu T, Xu Y, Jiang W, Zhu W, Tang Z, Ge Z, Ma T and Tan Y: Role of SB203580 in the regulation of human esophageal cancer cells under the effection of Diosgenin. Int J Clin Exp Med 8: 2476-2479, 2015.

30. Li Y, Wang X, Cheng S, Du J, Deng Z, Zhang Y, Liu Q, Gao J, Cheng B and Ling C: Diosgenin induces G2/M cell cycle arrest and apoptosis in human hepatocellular carcinoma cells. Oncol Rep 33: 693-698, 2015.

31. Mao ZJ, Tang QJ, Zhang CA, Qin ZF, Pang B, Wei PK, Liu B and Chou YN: Anti-proliferation and anti-invasion effects of diosgenin on gastric cancer BGC-823 cells with HIF-1 $\alpha$ shRNAs. Int J Mol Sci 13: 6521-6533, 2012.

32. Ganot N, Meker S, Reytman L, Tzubery A and Tshuva EY: Anticancer metal complexes: Synthesis and cytotoxicity evaluation by the MTT assay. J Vis Exp: e50767, 2013.

33. Livak KJ and Schmittgen TD: Analysis of relative gene expression data using real-time quantitative PCR and the 2(-Delta Delta C(T)) Method. Methods 25: 402-408, 2001.

34. Würstle ML, Laussmann MA and Rehm M: The central role of initiator caspase-9 in apoptosis signal transduction and the regulation of its activation and activity on the apoptosome. Exp Cell Res 318: 1213-1220, 2012.

35. Saleem M, Qadir MI, Perveen N, Ahmad B, Saleem U, Irshad $\mathrm{T}$ and $\mathrm{Ahmad} \mathrm{B}$ : Inhibitors of apoptotic proteins: New targets for anticancer therapy. Chem Biol Drug Des 82: 243-251, 2013.

36. Floyd DH, Zhang Y, Dey BK, Kefas B, Breit H, Marks K, Dutta A, Herold-Mende C, Synowitz M, Glass R, et al: Novel anti-apoptotic microRNAs $582-5$ p and 363 promote human glioblastoma stem cell survival via direct inhibition of caspase 3, caspase 9, and Bim. PLoS One 9: e96239, 2014. 
37. Ando M, Hoyos V, Yagyu S, Tao W, Ramos CA, Dotti G, Brenner MK and Bouchier-Hayes L: Bortezomib sensitizes non-small cell lung cancer to mesenchymal stromal cell-delivered inducible caspase-9-mediated cytotoxicity. Cancer Gene Ther 21: 472-482, 2014

38. Feng Y, He D, Yao Z and Klionsky DJ: The machinery of macroautophagy. Cell Res 24: 24-41, 2014.

39. Belaid A, Ndiaye PD, Klionsky DJ, Hofman P and Mograbi B: Signalphagy: Scheduled signal termination by macroautophagy. Autophagy 9: 1629-1630, 2013.

40. Klionsky DJ and Codogno P: The mechanism and physiological function of macroautophagy. J Innate Immun 5: 427-433, 2013.

41. Münz C: Regulation of innate immunity by the molecular machinery of macroautophagy. Cell Microbiol 16: 1627-1636, 2014.

42. Hönscheid P, Datta K and Muders MH: Autophagy: Detection, regulation and its role in cancer and therapy response. Int $\mathrm{J}$ Radiat Biol 90: 628-635, 2014.

43. Patel AS, Morse D and Choi AM: Regulation and functional significance of autophagy in respiratory cell biology and disease. Am J Respir Cell Mol Biol 48: 1-9, 2013.

44. Lorin S, Hamaï A, Mehrpour M and Codogno P: Autophagy regulation and its role in cancer. Semin Cancer Biol 23: 361-379, 2013.

45. Thorburn A, Thamm DH and Gustafson DL: Autophagy and cancer therapy. Mol Pharmacol 85: 830-838, 2014.

46. Polewska J: Autophagy-molecular mechanism, apoptosis and cancer. Postepy Hig Med Dosw (Online) 66: 921-936, 2012 (In Polish).

47. Chen HY and White E: Role of autophagy in cancer prevention. Cancer Prev Res (Phila) 4: 973-983, 2011.

48. Slobodkin MR and Elazar Z: The Atg8 family: Multifunctional ubiquitin-like key regulators of autophagy. Essays Biochem 55: 51-64, 2013.

49. Romao S and Münz C: LC3-associated phagocytosis. Autophagy 10: 526-528, 2014.

50. Rogov V, Dötsch V, Johansen T and Kirkin V: Interactions between autophagy receptors and ubiquitin-like proteins form the molecular basis for selective autophagy. Mol Cell 53: 167-178, 2014.

51. Gong J, Muñoz AR, Chan D, Ghosh R and Kumar AP: STAT3 down regulates LC3 to inhibit autophagy and pancreatic cancer cell growth. Oncotarget 5: 2529-2541, 2014.

52. Xia P and Xu XY: PI3K/Akt/mTOR signaling pathway in cancer stem cells: From basic research to clinical application. Am J Cancer Res 5: 1602-1609, 2015.
53. Cheaib B, Auguste A and Leary A: The PI3K/Akt/mTOR pathway in ovarian cancer: Therapeutic opportunities and challenges. Chin J Cancer 34: 4-16, 2015.

54. Polivka J Jr and Janku F: Molecular targets for cancer therapy in the PI3K/AKT/mTOR pathway. Pharmacol Ther 142: $164-175,2014$

55. Jiang YQ, Chang GL, Wang Y, Zhang DY, Cao L and Liu J: Geniposide prevents hypoxia/reoxygenation-induced apoptosis in H9c2 Cells: Improvement of mitochondrial dysfunction and activation of GLP-1R and the PI3K/AKT signaling pathway. Cell Physiol Biochem 39: 407-421, 2016.

56. Burris HA III: Overcoming acquired resistance to anticancer therapy: Focus on the PI3K/AKT/mTOR pathway. Cancer Chemother Pharmacol 71: 829-842, 2013.

57. Inoki K: mTOR signaling in autophagy regulation in the kidney. Semin Nephrol 34: 2-8, 2014.

58. Alers S, Löffler AS, Wesselborg S and Stork B: Role of AMPK-mTOR-Ulk1/2 in the regulation of autophagy: Cross talk, shortcuts, and feedbacks. Mol Cell Biol 32: 2-11, 2012.

59. Sangawa A, Shintani M, Yamao N and Kamoshida S Phosphorylation status of Akt and caspase-9 in gastric and colorectal carcinomas. Int J Clin Exp Pathol 7: 3312-3317, 2014.

60. Won KY, Kim GY, Lim SJ, Sung JY, Kim YW, Park YK, Lee J and Choi HS: Autophagy is related to the hedgehog signaling pathway in human gastric adenocarcinoma: Prognostic significance of Beclin-1 and Gli2 expression in human gastric adenocarcinoma. Pathol Res Pract 211: 308-315, 2015.

61. Zhong Y, Morris DH, Jin L, Patel MS, Karunakaran SK, Fu YJ, Matuszak EA, Weiss HL, Chait BT and Wang QJ: Nrbf2 protein suppresses autophagy by modulating Atg14L protein-containing Beclin 1-Vps34 complex architecture and reducing intracellular phosphatidylinositol-3 phosphate levels. J Biol Chem 289: 26021-26037, 2014.

62. Czabotar PE, Lessene G, Strasser A and Adams JM: Control of apoptosis by the BCL-2 protein family: Implications for physiology and therapy. Nat Rev Mol Cell Biol 15: 49-63, 2014.

63. Salminen A, Kaarniranta K and Kauppinen A: Beclin 1 interactome controls the crosstalk between apoptosis, autophagy and inflammasome activation: Impact on the aging process Ageing Res Rev 12: 520-534, 2013.

64. Fukui M, Yamabe N, Choi HJ, Polireddy K, Chen Q and Zhu BT: Mechanism of ascorbate-induced cell death in human pancreatic cancer cells: Role of Bcl-2, Beclin 1 and autophagy. Planta Med 81: 838-846, 2015. 